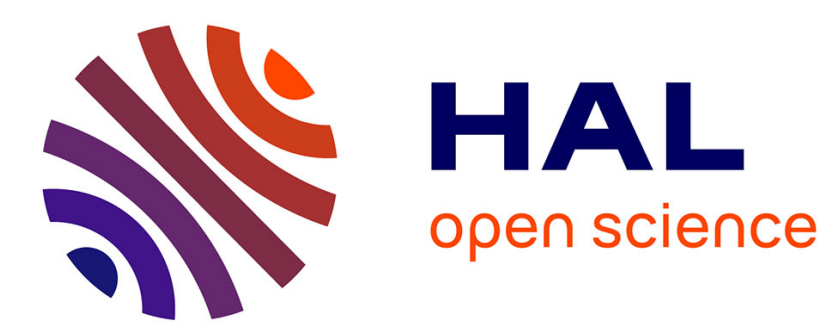

\title{
Volume changes at the magnetic transitions of UP
}

M. Steinitz, J. Grunzweig-Genossar

\section{To cite this version:}

M. Steinitz, J. Grunzweig-Genossar. Volume changes at the magnetic transitions of UP. Journal de Physique Colloques, 1979, 40 (C4), pp.C4-34-C4-35. 10.1051/jphyscol:1979412 . jpa-00218808

\section{HAL Id: jpa-00218808 https://hal.science/jpa-00218808}

Submitted on 1 Jan 1979

HAL is a multi-disciplinary open access archive for the deposit and dissemination of scientific research documents, whether they are published or not. The documents may come from teaching and research institutions in France or abroad, or from public or private research centers.
L'archive ouverte pluridisciplinaire HAL, est destinée au dépôt et à la diffusion de documents scientifiques de niveau recherche, publiés ou non, émanant des établissements d'enseignement et de recherche français ou étrangers, des laboratoires publics ou privés. 


\title{
Volume changes at the magnetic transitions of UP
}

\author{
M. Steinitz (*) and J. Grunzweig-Genossar \\ Department of Physics, Technion-Israel Institute of Technology, Haifa, Israel
}

\begin{abstract}
Résumé. - Nous avons mesuré la dilatation thermique d'un polycristal de monophosphure d'uranium (UP) à l'aide d'un dilatomètre capacitif de haute sensibilité. En chauffant nous observons à $22 \mathrm{~K}$ un changement de phase du premier ordre, accompagné d'une contraction $\Delta l / l=-6,8 \times 10^{-5}$. Le changement de phase à $22 \mathrm{~K}$ est inhabituel car il n'est pas accompagné d'un changement de symétrie. A $T_{\mathrm{N}}$ nous avons observé une dilatation brusque $\Delta l / l=+1,2 \times 10^{-5}$ qui indique un changement de phase du premier ordre, et non du second comme il est généralement admis.
\end{abstract}

\begin{abstract}
We measured the thermal expansion of a polycrystalline lump of uranium monophosphide, using a sensitive capacitance dilatometer. On heating, we observed at $22 \mathrm{~K}$ a first order phase change accompanied by a linear contraction of $\Delta l / l=-6.8 \times 10^{-5}$. This phase transition is unusual as it is not accompanied by any obvious symmetry changes. At $T_{\mathrm{N}}$ we observed a sudden expansion : $\Delta l / l=+1.2 \times 10^{-5}$, indicating a first order phase change, contrary to previous assumptions.
\end{abstract}

Uranium monophosphide UP orders antiferromagnetically at $T_{\mathrm{N}}=122.5 \mathrm{~K}$ and has an unusual first order symmetry-preserving transition at

$$
T_{\mathrm{t}}=22.5 \mathrm{~K}
$$

where the magnetic moment increases discontinuously with decreasing temperature. While in the other actinide monocompounds first order transitions similar to that at $T_{\mathrm{t}}$ in UP are accompanied by changes of magnetic order and by lattice distortions $[1,2]$, in UP this $22 \mathrm{~K}$ transition preserves the type AF-1 order and the crystal lattice remains cubic (within the limits of reported accuracy of $1 \times 10^{-5}$ ). Thus this transition is unusual as it is not accompanied by any obvious changes of symmetry. We report here on measurements which indicate that the sign of the volume change at $T_{\mathrm{t}}$ is opposite to that expected from models based on valency transitions, and that the Néel transition is of first order.

We have measured the thermal expansion of UP using a sensitive capacitance dilatometer. The specimen was a polycrystalline lump, $3.5 \mathrm{~mm}$ long in the direction measured. On heating, at $T_{\mathrm{t}}=22 \mathrm{~K}$ we observed a linear contraction of $\Delta l / l=-6.8 \times 10^{-5}$ extending over less than $1 / 4 \mathrm{~K}$ (Fig. $1 a$ ). In the vicinity of $30 \mathrm{~K}$ there appears to be a discontinuity in the coefficient of thermal expansion. Its origin is not clear at present. At the Néel point $T_{\mathrm{N}} \sim 123 \mathrm{~K}$ we observed a first order transition, showing a linear expansion of $\Delta l / l=+1.2 \times 10^{-5}$ (Fig. $\left.1 b\right)$. For comparison, we also include a graph of thermal expansion of a single crystal of UN in the vicinity of

(*) On leave from the Department of Physics, St. Francis Xavier University, Antigonish, Nova Scotia, Canada. its Néel point (Fig. $1 b$ insert). The transition in UN is clearly of second order, in contrast to that in UP.

Marples [3] interpreted his X-ray diffraction data as showing a negative thermal expansion coefficient

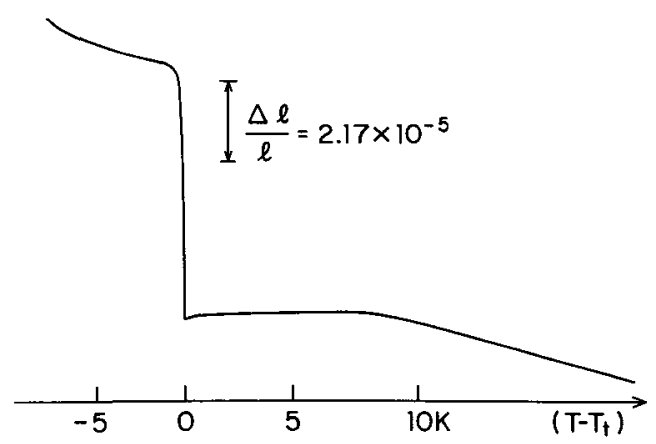

a)

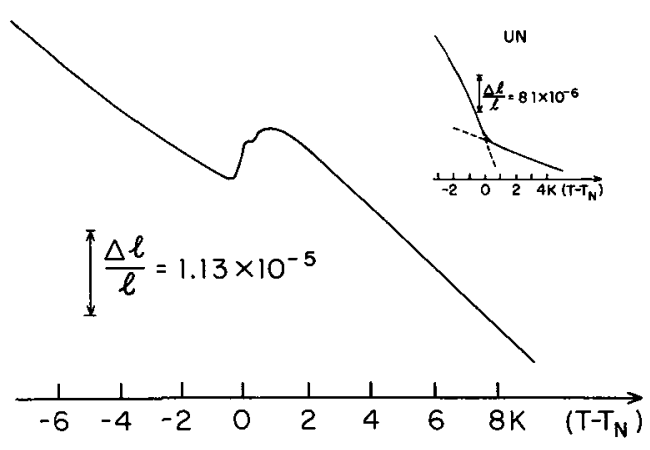

b)

Fig. 1. - Thermal expansion of UP relative to beryllium-copper cell. Direct tracing of dilatometer output (cell capacitance) against thermocouple E.M.F. $:(a)$ in the vicinity of $T_{1}=22.5 \mathrm{~K} ;(b)$ in the vicinity of the Néel point $T_{\mathrm{N}}=122.5 \mathrm{~K}$; Insert : Thermal expansion of UN in the vicinity of the Néel point $T_{\mathrm{N}}=53 \mathrm{~K}$. 
between helium temperatures and the $22 \mathrm{~K}$ transition point, where there is a discontinuous change, the expansion coefficient becoming positive and gradually increasing with temperature, with no discontinuity at the Néel point. Nasu et al. [4] observed a slight local minimum of the coefficient of thermal expansion at $124 \mathrm{~K}$ (about $2 \times 10^{-6} \mathrm{~K}^{-1}$ ) followed by a sudden, very narrow and high peak (about $40 \times 10^{-6} \mathrm{~K}^{-1}$ ) several degrees higher, which, as far as can be judged from a very small scale graph available to us, is similar to our results near $T_{\mathrm{N}}$.

Discussion. - Attempts have been made to explain the general electronic and magnetic properties of the uranium monocompounds either in terms of localized uranium valency states [5] or of a narrow 5-f band [6]. Neither model is really satisfactory. In order to interpret the $22 \mathrm{~K}$ transition in UP, Long and Wang [7] assumed additional electrostatic multipole interactions between localized uranium ions. With the proper choice of parameters, they could reproduce the low-temperature variation of the sublattice magnetization over a limited temperature range, including the jump at $22 \mathrm{~K}$. Robinson and Erdos [8] assumed that, at low temperature, the 5f electrons partially reside in localized states on $\mathrm{U}^{4+}$ ions, and partially as $6 \mathrm{~d}-7 \mathrm{~s}$ band electrons. On heating, at $T_{t}$, a large fraction of the band electrons condenses converting most $\mathrm{U}^{4+}$ into $\mathrm{U}^{3+}$ ions. With proper choice of a large number of free parameters, they can reproduce the temperature variation of magnetization, of susceptibility, and the entropy changes. They obtain two first order transitions in UP, one at $T_{t}$, where the concentration of bound electrons drops suddenly from 1.2 to 0.2 per atom, followed by a gradual increase of the band population with temperature, rising to about 0.4 followed by a sudden jump to about 0.6 electron/atom at the Néel point.

In analogy with similar valency changes in rareearth compounds (e.g. SmS), one would expect that such large changes in the average valency of the uranium ions should be accompanied by a significant ( $\sim 1 \%$ ) change in linear dimensions at $T_{\mathrm{t}}$ and about 10 times less at $T_{\mathrm{N}}$. However, the dimensional changes reported here are about $10^{3}$ times smaller and are opposite in sign to those expected from the valency changes postulated above. Robinson and Erdos were aware that the absence of volume expansion presents a problem and quoted other cases of valency transitions which apparently are not accompanied by large volume changes. However, we think that the small volume changes observed by us may perhaps be accounted for by magnetostrictive effects, and the absence of large volume changes, especially at $T_{\text {t }}$, indicate that this transition does not involve any significant valency changes. Thus the problem of the moment- jump-transition in UP and, in general, of its electron band structure still await solution.

We are grateful to Dr. M. Mueller and to Dr. G. Lander of the Argonne National Laboratory for the kind loan of specimens.

\section{References}

[1] Lander, G. H. and Mueller, M. H., Phys. Rev. B 10 (1974) 1994.

[2] Marples, J. A. C., Sampson, C. F., Wedgwood, F. A. and Kuznietz, M., J. Phys. C 8 (1975) 708.

[3] Marples, J. A. C., J. Phys. Chem. Solids 31 (1970) 2431.

[4] NASU, S., OMICHI, T. and KIKUCHI, T., Japan AERI-memo 2613 (1967).

[5] Grunzweig-Genossar, J., KuZnietz, M. and Friedman, F., Phys. Rev. 173 (1968) 562.
[6] DAvies, H. L., in the Actinides : Electronic Structure and Related Properties. A. F. Freeman and J. B. Darby Jr. eds. (Academic Press, New York) 1974, Vol. II, p. 1.

[7] Long, C. and Wang, Y. L., Phys. Rev. B 3 (1971) 1656.

[8] Robinson, J. M. and Erdos, P., Phys. Rev. B 8 (1973) 4333, ibid. B 9 (1974) 2187. 